\title{
A Step Further in Tolerance: Recognition, Respect, Appreciation, and Acceptance
}

Rukya Hassen*

Kotebe Metropolitan University, Ethiopia

Submission: January 18, 2018; Published: May 07, 2018

*Corresponding author: Rukya Hassen, Kotebe Metropolitan University, Ethiopia, Email: rukyahassens@gmail.com

Keywords: Recognition; Respect; Appreciation; Acceptance; Tolerance; Wollo; Acquired; Cultured; Mewlid holiday; Communication culture;

Reproductive; Legitimacy; Trinity; Tsebel; Fragrance

\section{Religious Tolerance in Wollo: Acquired and Cultured}

The Muslim-Christian society of Wollo has peacefully coexisted for a long time. Tolerance is a very important value which they have maintained. In their language use, it appears to be an important discourse that has been valued by the people [1]. For example, in the poems of Sheikh Hussein Jibril, the following verses are found:

$$
\begin{gathered}
\text { 'ityop'ya 'agaraččən raswan tasarta tabla ləkkək } \\
\text { taqabbətawallač bahambar baməsk } \\
\text { təšattaččawallač laroma laturk } \\
\text { basamay 'ayəroplan bamaret lay tank } \\
\text { 'əyamat't'u qarru 'əyyalu ləkkək } \\
\text { hayəla səllase naw balwamma ballək } \\
\text { 'ənnam du'a 'argannal səllase yəbark }
\end{gathered}
$$

Our country Ethiopia gets her hair done well,

She wears perfume and good fragrance,

Rome and Turkey smells her,

with plane on the air and with tank on the ground,

They have come and stayed fit,

Hailesilasie is her right husband though,

We have prayed; let the Trinity bless it.

The last verse of this poem states that the Muslims pray to their God and the Trinity (Christian's God) also bless Ethiopian.

\begin{tabular}{|c|c|}
\hline 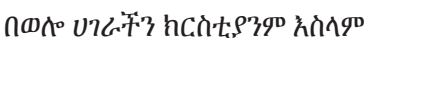 & $\begin{array}{l}\text { In our homeland Wollo, } \\
\text { Muslims and Christians }\end{array}$ \\
\hline 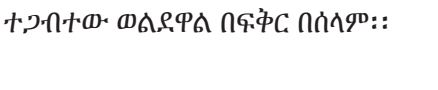 & $\begin{array}{l}\text { established blood relations } \\
\text { with love, }\end{array}$ \\
\hline 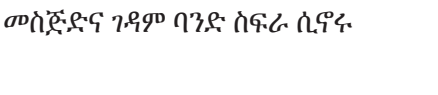 & $\begin{array}{l}\text { Mosque and Church are } \\
\text { built at one place }\end{array}$ \\
\hline 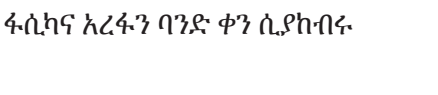 & $\begin{array}{l}\text { They celebrate both Arafa } \\
\text { and Easter together }\end{array}$ \\
\hline 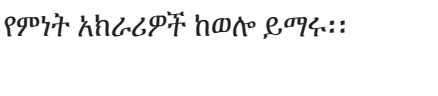 & $\begin{array}{l}\text { Extremists should learn } \\
\text { from Wollo. }\end{array}$ \\
\hline 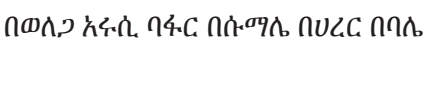 & $\begin{array}{l}\text { In Wollaga, Arsi, Afar, } \\
\text { Somale, Harar and Bale }\end{array}$ \\
\hline 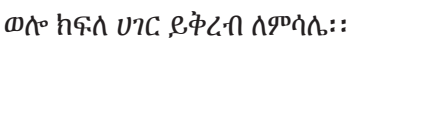 & $\begin{array}{l}\text { Let the experience of } \\
\text { Wollo be presented as } \\
\text { example. }\end{array}$ \\
\hline
\end{tabular}
This implies that the poet accepts the legitimacy of both religions as sacred. Such expressions are used for the purpose of solidarity.
The people of Wollo live tolerance. They have owned it [2]. They have valued, cultured and made it their habit. On a Mewlid holiday ceremony, one Wolloye Said the following:

As explained in the extract, the experience of the practice of religious tolerance in Wollo is exemplary. Religious tolerance is acquired and cultured in Wollo. The Muslim-Christian society of Wollo has peacefully co-existed for a long time [3]. Tolerance is a very important value which they have maintained. In their language use, it appears to be an important discourse that has been valued by the people. For example, in the poems of Sheikh Hussein Jibril, the following verses are found:

$$
\begin{aligned}
& \text { ’ityop’ya 'ägäraččəñ raswan täsärta täbla ləkkək } \\
& \text { täqäbbətawalläč bähämbär bäməsk } \\
& \text { təšättaččäwalläč läroma läturk }
\end{aligned}
$$


bäsämay 'äyəroplan bämäret lay tank

'əyämät't'u qärru ’əyyalu ləkkək

häyəlä səllase näw balwamma bällək

’əññam du’ä 'ärgännal səllase yəbark

Our country Ethiopia gets her hair done well,

She wears perfume and good fragrance,

Rome and Turkey smells her,

with plane on the air and with tank on the ground,

They have come and stayed fit,

Hailesilasie is her right husband though,

We have prayed; let the Trinity bless it. (74)

The last verse of this poem states that the Muslims pray to their God and the Trinity (Christian's God) also bless Ethiopian. This implies that the poet accepts the legitimacy of both religions as sacred. Such expressions are used for the purpose of solidarity $[4,5]$.

\section{A Step Further in Tolerance: Recognition, Respect, Appreciation, and Acceptance (Figure 1)}

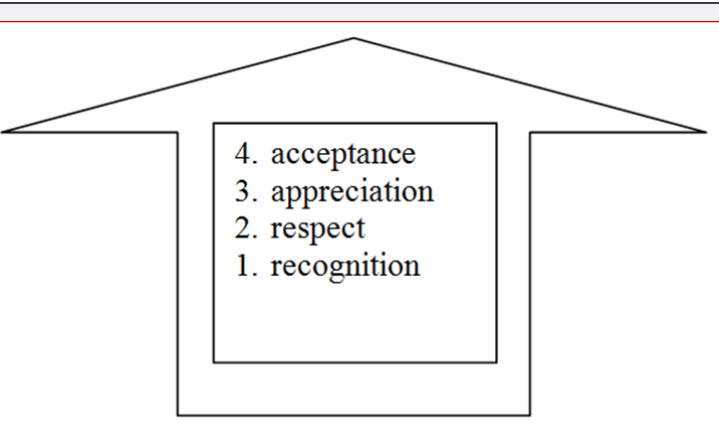

Figure 1: A Step Further in Tolerance: Recognition, Respect, Appreciation, and Acceptance.

Tolerance requires recognition, respect and appreciation of different ways of living. The diversified community of the world need to recognize each other's different ways of living; respect it as it naturally is; and if possible appreciate each other's systems of living. If the diverse world community manages to do just these, it can be said that they practice tolerance.

As the community themselves describe their communication culture and as the researcher has observed them, the Wollo community is doing much more than these. There is one more step further in practicing tolerance. The Wollo community understands the value of tolerance and develops it to its possible highest level [6].
The Wollo people do not stop at appreciation, but take one further step forward and accept and practice the different systems. They practice each others' systems as observed in the following discourse as social practices.

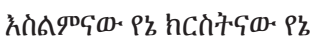

Islam is mine, Christianity is mine

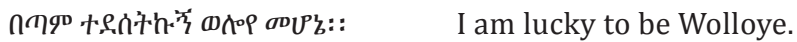

Some of the discourses that the people own are the following:

a. There are some discourses that the people adopt and practice at the same label and practice. For example, wodaja which is a Muslim cultural practice is adopted by the Christians and 'tsebel' which is a Chrisian cultural practice is adopted by the Muslims of the area.

b. There are some discourses that the people adapt and practice which has different label with the same practice or same label with different practice. For instance, 'Yayn Lij' is a label given by the Muslims for God child. This practice has been owned by the Muslims. Interceding is a social practice of both Muslims and Christians with different practice.

c. There are some discourses that the people do not practice but consider it as right in itself. They do not own and practice the discourse but they consider it as another way of doing it right. Such practices include wearing style, sitting style, eating style, and washing (reproductive organs, ablution).

d. There are some discourses that the people do not practice but consider it as own that belong here. Such kinds of social practices are believed to be wrong. But they believe 'some of us do it this way and it is ok'. Such social practices include the basic religious practices.

\section{References}

1. Ahmedin Jebel (2003) Ethiopian Muslims: From 615-1700 a History of Coercion and Struggle. pp. 195.

2. Amsalu Aklilu, Habtemariam Markos (1969) The Dialect of Wollo. Unpublished mimeographed Paper, Addis Ababa University, Ethiopia.

3. Amsalu Aklilu (1987) The Influence of Arabic on Ethiopian Languages. A Paper Presented on Afro Arab Relations Colloquium. Khartoum. In Language Miscellanea. IES AAU p. 34-56.

4. Bauman R, Sherzer J (1989) Explorations in the Ethnography of Speaking. New York: Cambridge University Press, USA.

5. Biber D, Conrad S, Reppen R (1998) Corpus Linguistics: Investigating language Structure and Use. Cambridge: Cambridge University Press, USA.

6. Bogale T (1984) Prophesies of Sheikh Husien Jibril. Nigd printing Press: Addis Ababa, Ethiopia. 

(C) This work is licensed under Creative BY

DOI: 10.19080/GJAA.2018.04.555626
Your next submission with Juniper Publishers

will reach you the below assets

- Quality Editorial service

- Swift Peer Review

- Reprints availability

- E-prints Service

- Manuscript Podcast for convenient understanding

- Global attainment for your research

- Manuscript accessibility in different formats

( Pdf, E-pub, Full Text, Audio)

- Unceasing customer service

Track the below URL for one-step submission https://juniperpublishers.com/online-submission.php 